This occured because the salaries they expected to receive from these projects were lower than the UNHCR assistance offered to them until the project reached self-sufficiency. It is this seemingly rational behaviour of refugees that the CONAPARE study coined "irresponsible" (see above). It is often argued that prolonged emergency assistance by the UNHCR creates a "dependent" population unwilling to work.

Presently, this "problem" no longer exists since UNHCR emergency assistance was discontinued to all Salvadorean refugees in Costa Rica in December 1985. There is a greater incentive for the refugees to stay in the projects. On the other hand, the burden of providing subsistence to the project beneficiaries has shifted entirely to implementing agencies. The latter are required to offer more financial assistance per project and this results in the decline in the number of businesses these agencies are capable of implementing. For instance, the number of projects administered by the Episcopalian Church has decreased from 18 to 7 in the last year.

While the UNHCR solved the problem of a "dependent population", the Costa Rican government is not absorbing those "independent" wage-labourers who are not integrated into projects. In September 1984, a law allowing Salvadorean refugees to work was passed. However, it does not mean that a refugee can apply for the job of his choice. Instead, he has to find a job, get a letter from his employer and then apply for a permit to PRIMAS (Programa para Refugiados del Instituto Mixto de Ayuda Social). He then has to wait three to four months to get his application approved.

This procedure is in accordance with the Costa Rican policy of protecting the national labour force. According to the Labour Code of the country, a firm is to employ workers at least $90 \%$ of whom should be Costa Rican, who should receive at least $85 \%$ of the salaries. Thus, before granting a permit for work to an applicant, PRIMAS officials make sure that these conditions are observed. Of course, no employer is willing to wait for three or four months for a potential worker to get a permit. Given that a permit is often denied, a refugee loses three or four months awaiting a permit and not looking for any other job.

Why does the Costa Rican government fail to fulfil its responsibilities towards Salvadorean refugees? Certain justifications can be provided. Starting in 1979, the economic crisis in Costa Rica became evident. Between the beginning of 1980 and March 1982, the number of openly unemployed people more than doubled: it rose from 35,00 to 79,000 people. While in 1980 only $5 \%$ of the population of the country was unemployed, by 1983 the unemployment rate had reached $8.9 \%$. While in July $1979,246,000$ people faced employment problems, by 1982 the number had risen to 481,000 . The crisis hit the urban labour force relatively harder. In July 1983, the open unemployment rate in rural areas was $8.3 \%$ and, in urban areas, $12.2 \%$. Salaried workers were the major victims of unemployment as $51 \%$ of those who lost their jobs in 1980-82 were in that category. Given the growing unemployment in Costa Rica, it is clear that refugees are in direct competition for jobs with the local labour force.

In sum, most of the "durable solutions" projects for Salvadorean refugees in Costa Rica have failed. Some causes have to do with the refugees' lack of technical and administrative skills. These shortcomings can be overcome by offering training courses to project beneficiaries. Most errors committed by the agencies have by now been acknowledged by them and agencies are adopting a more rational research and planning approach to project implementation.

The Costa Rican government policy towards economic integration of the refugees presents more serious problems. The government cannot open doors to salaried jobs to refugees without endangering the national labour force. Therefore, while de jure refugees have a right to work, de facto their access to jobs is blocked by bureaucratic procedures. At the same time, without UNHCR emergency assistance, voluntary agencies can implement a limited number of projects.

What is to be done with those refugees who are neither incorporated into projects nor allowed to work for wages? There are two alternatives: directing more development funds into the projects for Salvadorean refugees in Costa Rica and/or increasing immigration to third countries. Canadian government and voluntary agencies can play an important role in both solutions.

Tanya Basok, a doctoral candidate in Sociology affiliated with the Refugee Documentation Project at York University, is presently in Costa Rica undertaking research on the resettlement of Salvadorean refugees.

\section{News Digest}

- Historians, conflict researchers as well as specialists in public international law are involved in a major refugee research project launched by the Department of History, University of Lund, Sweden. The focus of the project is on the period 1943-1954. Although the problem of uprooted Europeans will be central to the study, the latter will not be limited to Europe and will analyse also U.S. refugee policy during this period. For further information please contact Professor Göran Rystad, Department of History, University of Lund, Magle Lilla Kyrkogata 9 A, S-223 51 Lund, Sweden.

- For ten years Connexions has acted as a nation-wide forum for the social change community in Canada. It has now launched the Connexions Directory of Canadian Organizations for Social Justice. The Directory includes address and telephone listings for over 1,500 groups working for social change. It will be updated annually. The Connexions Directory is available for $\$ 17.95$ from Connexions, 427 Bloor Street West, Toronto, Ontario, Canada M5S 1X7, Tel.: (416) 960-3903.

- The Center for Migration Studies is publishing a special Spring issue of the International Migration Review focusing on refugee assistance and policy issues. This special issue, with an introduction by Dennis Gallagher of the Refugee Policy Group, will contain an impressive collection of articles on the following topics: refugee movements, asylum and protection, refugee issues in developing countries, and adjustment and resettlement. To order copies contact CMS, 209 Flagg Place, Staten Island, New York 10304, U.S.A.

- An annual publication of the U.S. Committee for Refugees, the World Refugee Survey includes extensive country reports, statistics, a directory of agencies and organizations working to meet refugees' needs, and a bibliography. The 1985 Survey includes contrasting views on U.S. asylum policy, articles on the "land Vietnamese" in Thailand, the situation of refugees from Chad, the protection of undocumented Salvadoreans in the United States, a personal account of the refugee situation in the Sudan, a look at the role of black Americans in helping refugees, and updates on refugee women and Soviet Jews. Single copies of the Survey sell for U.S.\$6.00. All requests for surveys should be sent to Gary Young, U.S. Committee for Refugees, 815 15th St., N.W., Suite 610, Washington, D.C. 20005, U.S.A. 